\title{
Reduction of Tetrachloroaurate(III) Ions With Bioligands: Role of the Thiol and Amine Functional Groups on the Structure and Optical Features of Gold Nanohybrid Systems
}

\author{
Ditta Ungor ${ }^{1}\left[\right.$, Imre Dékány ${ }^{1}$ and Edit Csapó ${ }^{1,2, *(1)}$ \\ 1 Interdisciplinary Excellence Centre, Department of Physical Chemistry and Materials Science, \\ University of Szeged, Rerrich B. square 1, H-6720 Szeged, Hungary \\ 2 MTA-SZTE Biomimetic Systems Research Group, Department of Medical Chemistry, University of Szeged, \\ Dóm square 8, H-6720 Szeged, Hungary \\ * Correspondence: juhaszne.csapo.edit@med.u-szeged.hu; Tel.: +36-62-544-476
}

Received: 23 July 2019; Accepted: 26 August 2019; Published: 29 August 2019

\begin{abstract}
In this review, the presentation of the synthetic routes of plasmonic gold nanoparticles (Au NPs), fluorescent gold nanoclusters (Au NCs), as well as self-assembled Au-containing thiolated coordination polymers (Au CPs) was highlighted. We exclusively emphasize the gold products that are synthesized by the spontaneous interaction of tetrachloroaurate(III) ions $\left(\mathrm{AuCl}_{4}^{-}\right)$with bioligands using amine and thiolate derivatives, including mainly amino acids. The dominant role of the nature of the applied reducing molecules as well as the experimental conditions (concentration of the precursor metal ion, molar ratio of the $\mathrm{AuCl}_{4}{ }^{-}$ions and biomolecules; $\mathrm{pH}$, temperature, etc.) of the syntheses on the size and structure-dependent optical properties of these gold nanohybrid materials have been summarized. While using the same reducing and stabilizing biomolecules, the main differences on the preparation conditions of Au NPs, Au NCs, and Au CPs have been interpreted and the reducing capabilities of various amino acids and thiolates have been compared. Moreover, various fabrication routes of thiol-stabilized plasmonic Au NPs, as well as fluorescent Au NCs and self-assembled $\mathrm{Au} C P s$ have been presented via the formation of $-(\mathrm{Au}(\mathrm{I})-\mathrm{SR})_{\mathrm{n}}$ - periodic structures as intermediates.
\end{abstract}

Keywords: gold nanoparticles; gold nanoclusters; coordination polymer structure; amino acids; template-assisted synthesis; fluorescence; $\mathrm{Au}(\mathrm{I})$-thiolate; gold nanohybrid materials

\section{Introduction}

Nowadays, the development of diverse nanostructured materials have a dominant role in several physical, chemical, medical, etc. fields from the electronics to the food industries [1,2]. The noble metal nanoparticles are extremely investigated nano-objects due to their electric, magnetic and unique morphology, size, and composition-dependent optical features [3,4]. This optical property originates from the so-called localized surface plasmon resonance (LSPR) phenomena, which results in the appearance of a characteristic plasmon band in the $400-800 \mathrm{~nm}$ range of the electromagnetic spectra [5,6]. In the last two-three decades, gold nanoparticles (Au NPs) have became increasingly the focus of interests in the material and medical sciences thanks to the advantageous physicochemical properties, such as large specific area, chemical inertness, and tunable optical particularity [7]. Several methods for fabrication of nano-sized Au NPs are known in the literature, including the physical (e.g., physical vapor deposition (PVD), microwave (MW) or ultraviolet (UV) radiation, ball milling or photoreductive routes, etc. [8,9]) and chemical approaches $[3,4,10]$. In the latter case, depending on 
the applied reducing and stabilizing agents (e.g., sodium borohydride [11,12], sodium citrate [13-15], surfactants [16,17], various amines [18], peptides [19,20], or biological organisms [21-23]), particles of different shapes and sizes can be produced. In the last decade, the sub-nanometer sized gold nanoclusters (Au NCs) have also became increasingly dominant. Beside the Au NPs, the Au NCs are also in the focus of researches. These ultra-small metal objects consist of only a few of few tens' gold atoms, and generally the oxidation number of the $\mathrm{Au}$ is $<1$ and $\mathrm{Au}-\mathrm{Au}$ bonds can be found in the clusters. By the mentioned structure, the Au NCs show unique size-tunable photoluminescence (PL) due to the well-defined molecular structure and discrete electronic transitions [24-26]. The blue-emitting Au NCs usually only contain a few atoms, thus the emission band depends only on the number of atoms in the cluster and the PL lifetime occurs in the nanosecond range. Nevertheless, if the size of the $\mathrm{Au}$ NCs achieves the few-nanometer range $(\mathrm{d} \sim 1.5-2.0 \mathrm{~nm})$, the characteristic emission band is detected in the orange and in the red visible region. In this case, the surface ligand effect and the oxidation state of the surface metal atoms both influence the location of the emission maximum and the PL lifetime reaches the microsecond range. The larger colloidal Au NPs $(\mathrm{d} \sim 2-10 \mathrm{~nm})$ possess weak PL, which is regulated by the surface roughness and the grain size effect [27]. Based on the above-mentioned structure-depending optical features, the sub-nanometer Au NCs can potentially be used as optical probes for biosensing, bio-labelling, and bioimaging applications [24,26,27].

The biomedical applications (cancer therapy, diagnostics, and bioimaging, etc.) of nano-sized functionalized $\mathrm{Au}$ particles/clusters require biocompatible preparation routes with mild reaction conditions. Nowadays, the practical one-step "green" preparation protocols of several water-soluble $\mathrm{Au}$ NPs/NCs are extremely preferred [21,28-30]. During these processes, mainly the template-assisted preparation approaches are used, where dominant amines, like simple amino acids [31], peptides or proteins [32,33], dendrimers [34,35], and nucleotides [36-39], are applied, which have simultaneously a dual role as reducing and stabilizing ligand. The amines are a crucial class of the possible reducing agents, because they can be found in biological and chemical atmospheres. Main advantages of this relatively simple template-directed reduction technique are that no additional reducing agent is required and based on the well-defined structure of polypeptides and proteins uniform NPs/NCs with tunable optical features can be synthesized. Besides amines, the thiol group-containing molecules (e.g., thiolates) can coordinate and reduce the Au ions at the same time to form periodic - $(\mathrm{Au}(\mathrm{I})-\mathrm{SR})_{\mathrm{n}}-$ structures/complexes having partially reduced $\mathrm{Au}(\mathrm{I})$ ions, which are a well-known intermediates in the fabrication route of thiol-covered gold nanohybrid systems [40-43]. Several researches focus on the better understanding of the unknown structures of so-called atomically precise thiolate-protected $\mathrm{Au}$ NCs or the possible utilization of the thiolate-stabilized Au NPs/NCs [43-45]. In addition to the thiol-protected Au NPs/NCs, the study of the formation of Au-thiolate so-called "coordination polymer structure", having $\mathrm{Au}^{0}$ or mostly $\mathrm{Au}(\mathrm{I})$ is in focus of interest. These coordination polymers (CPs) are inorganic-organic hybrid materials, which consist of periodic metal ions/atoms and ligand moieties and possess ordered structure. The self-assembly of this structure results in the formation of lamellar multilayers or helical structures with unique optical properties [41,46,47].

In recent work, we aim to provide an overview that is focused on the summary of the preparation routes, the unique structure, as well as the structure-dependent optical features of Au NPs, Au NCs, and $\mathrm{Au} \mathrm{CP}$ structures that are synthesized by template-assisted synthesis exclusively using amines (mainly simple amino acids) and thiol-group containing molecules (e.g., thiolates) as possible reducing and stabilizing molecules. We mainly emphasize the formation of Au NPs, Au NCs, and Au CPs, which are fabricated by the direct interaction of tetrachloroaurate(III) ions $\left(\mathrm{AuCl}_{4}{ }^{-}\right)$with amino acids and alkyland arylthiolates in the absence of other reducing agents. We clearly summarize the dominant effect of the metal ion concentration, the molar ratio of the precursor aurate ions and reducing bioligands, as well as the experimental conditions (e.g., reaction time, temperature, $\mathrm{pH}$, etc.) on the tunable, structure-dependent optical properties (plasmonic or fluorescence) of the Au nano-objects. 


\section{Preparation of Amino Acid-Reduced Colloidal Au NPs Having Plasmonic Property}

There are several publications all around the world that describe the possible chemical synthesis routes of Au NPs in aqueous or in organic media. The well-known Brust method provides uniform alkyl or arylthiol-protected $\mathrm{Au} N \mathrm{NP}(\mathrm{d}=1-5 \mathrm{~nm})$ reduced by sodium borohydride $\left(\mathrm{NaBH}_{4}\right)$ in toluene [11], while in aqueous medium the conventional method is the Turkevich process, which results in the formation of water-soluble Au NPs in the range of 5-50 nm reduced and stabilized by sodium citrate [13]. In the last decade, various other reduction and caption possibilities were examined, where bacteria and microorganisms [48,49], plant extracts [50,51], inorganic reagents [52], metal complexes [53,54], organic and physiological molecules [55,56], polymers [57,58], liposomes [59], etc. have been tested. Due to the biocompatible nature, easy accessibility, and remarkable reducing capabilities, the amino acids and their derivatives are used dominantly [60] to produce biocompatible noble metal NPs. As far as we know, to date, all the twenty naturally occurring amino acids were investigated. In 2002, Mandal et al. published firstly the formation of Au NPs having spherical shape and monodisperse size distribution $\left(\mathrm{d}=25 \mathrm{~nm}\right.$ ) by spontaneous interaction of $\mathrm{AuCl}_{4}{ }^{-}$with L-aspartic acid (Asp) under boiling condition while using $\mathrm{AuCl}_{4}{ }^{-}$:Asp ca. 1:11 molar ratio [61]. Under the same experimental conditions, the synthesis was carried out with L-valine (Val) and L-lysine (Lys), but no reduction of $\mathrm{AuCl}_{4}{ }^{-}$was observed and during preparation, the role of the $\mathrm{pH}$ was not mentioned. Next year, the reduction capability of Lys was studied again [62], but Au NPs in the range of 6-7 nm could only be prepared at room temperature by the application of extra $\mathrm{NaBH}_{4}$ reductant as well. The hydrogen bonds between the surface-bound Lys molecules of the adjacent Au NPs was confirmed by NMR studies. Through the researches of Mandal, Selvakannan, and Sastry [63], L-tryptophan (Trp)-stabilized gold colloids was also efficiently fabricated. The synthesis was carried out at $50{ }^{\circ} \mathrm{C}$ while using $\mathrm{AuCl}_{4}{ }^{-}$:Trp ca. 1:100 molar ratio. ${ }^{1} \mathrm{H}$ NMR studies clearly indicated the indole-based polymerization of Trp, which contributed to the better understanding of the reduction process of Trp with $\mathrm{AuCl}_{4}{ }^{-}$ forming Au NPs under mild reaction conditions without application of other harsh reducing agents like $\mathrm{NaBH}_{4}$. In 2005, Bhargava et al. summarized the successful fabrication of Au NPs by spontaneous interaction of potassium tetrabromoaurate(III) precursor $\left(\mathrm{KAuBr}_{4}\right)$ with L-tyrosine (Tyr) and L-arginine (Arg) at room temperature while using ca. 1:4 metal ion to amino acid molar ratios under alkaline medium [64]. For Tyr-reduced Au NPs having 5-40 nm in size, a slightly polydisperse distribution and coagulations of the NPs were observed. The Arg-produced colloidal NPs have larger size than the average diameter of Tyr-reduced particles, but the size distribution showed much narrower shape. The cyclic voltammetry $(\mathrm{CV})$ studies of Blanchard et al. provided important information regarding the reduction abilities of various amines, including amino acids L-glycine (Gly) and Trp, as well as the proposed reduction mechanism between metal ions and bioligands [65]. Presumably, the reduction of aurate ions occurs thanks to the electron transfer from amines to the metal ions resulting in $\mathrm{Au}$ atoms with zero oxidation state and finally the nucleation and growth steps eventuates the formation of NPs. This redox reaction results in the appearance of short chain amine oligomers, which is confirmed by NMR studies. Moreover, the oxidation potential of amines, which are used for the reduction of gold ions, has outstanding impact on the formation of Au NPs considering the reduction potential of $\mathrm{AuCl}_{4}{ }^{-}$. Amines that have redox potential between the oxidation of $\mathrm{Au}^{0}$ to gold(I) and the reduction of tetrachloroaurate(III) to $\mathrm{Au}^{0}$ can be suitable used as reducing agents. L-Glutamic acid (Glu)-reduced $\mathrm{Au}$ colloids were also previously fabricated, having a particle size of $\mathrm{d}=40 \mathrm{~nm}$, but the synthesis was carried out under refluxing [66]. In 2010, the hydrothermal synthesis of the L-histidine (His)-reduced spherical Au NPs. The average diameter was $11.5 \mathrm{~nm}$ reported by Liu et al., where the $\mathrm{AuCl}_{4}{ }^{-}: \mathrm{His} / 1: 2.5$ molar ratio was used at $150{ }^{\circ} \mathrm{C}$ in alkaline ( $\mathrm{pH}$ 11.50) medium [67]. The structural characterization of His-protected Au NPs supported that the terminal $\mathrm{COO}^{-}$group of His was not attached of the particle surface, while the imidazole as well as the amino groups were adsorbed on the Au surface. The construction of His-stabilized Au NPs did not occur at room temperature, but the hydrothermal conditions (e.g., high temperature and pressure) facilitate the formation of Au crystals. Besides the above-mentioned amino acids (Asp, Lys, Trp, Tyr, Glu, His), the reduction capabilities of L-aspartate 
(Asp), Gly, L-leucine (Leu), Lys, and L-serine (Ser) were also published by the work of Cai et al. in 2014 [68], but they used extra UV irradiation during the synthesis. The different Au NPs have diameters of $15-47 \mathrm{~nm}$ and the synthesis was carried out at $\mathrm{pH} 10.0$ while using 1:10/ $\mathrm{AuCl}_{4}{ }^{-}: \mathrm{amino}^{-}$ acid molar ratios. Maruyama et al. studied the spontaneous interaction of each natural amino acids with aurate ions using high bioligand excess (metal ion to ligand ca. 1:100) at $80{ }^{\circ} \mathrm{C}$, and they obtained that L-cysteine (Cys) and L-threonine (Thr) did not provide gold colloids. However, for L-methionine (Met) and L-phenylalanine (Phe), Au NPs were formed, but these colloids were easily precipitated. In 2014, L. Courrol and R. Almeida de Matos summarized their results in a book Chapter [69], where the formation of plasmonic Au colloids was confirmed by spontaneous interaction of aurate ions with Asp, Arg, Thr, Trp and Val using electromagnetic radiation (xenon lamp) at different $\mathrm{pH}$ using ca. 1:5 metal ion to amino acid molar ratios. However, the reduction capability of Trp was previously identified [70], but E. Csapó et al. clearly confirmed that the ratio of the precursor $\mathrm{AuCl}_{4}{ }^{-}$and the bioligand greatly influences the optical feature of the formed colloids [71]. Using $\mathrm{AuCl}_{4}{ }^{-}: \operatorname{Trp} / 1: 0.4$ molar ratio in alkaline medium ( $\mathrm{pH}=12.0)$, plasmonic Trp-Au NPs $\left(\lambda_{\mathrm{abs}}=530 \mathrm{~nm}\right)$ were formed (Figure 1B). Based on the best of our belief, this work supported firstly that high ligand excess is no necessary for synthesizing Trp-reduced $\mathrm{Au}$ NPs at mild $\left(37^{\circ} \mathrm{C}\right)$ temperature. The presence of stable monodisperse Au NPs was confirmed by DLS $\left(\mathrm{d}_{\text {DLS }}=8.8 \pm 1.0 \mathrm{~nm}\right)$ and HRTEM $\left(\mathrm{d}_{\text {HRTEM }}=7.8 \pm 0.3 \mathrm{~nm}\right)$ studies. Moreover, depending on the applied molar ratios of the $\mathrm{AuCl}_{4}{ }^{-}: \operatorname{Trp}$, structure-dependent tunable optical property was also obtained. Namely, at acidic conditions $(\mathrm{pH}=1.0)$, in the case of the mixing of Trp and $\mathrm{AuCl}_{4}{ }^{-}$solutions, the intensive yellow color of the solution changed to dark yellow after a few minutes. Below 1:1 ratio, unstable Au colloids was formed, but the application of molar ratio between $\mathrm{AuCl}_{4}{ }^{-}: \operatorname{Trp} / 1: 1$ and 1:15 resulted in luminescent products. The appearance of the emission peak depends of the ligand excess, namely the maximum value can be detected at $\lambda_{\mathrm{em}}=497 \mathrm{~nm}$ $\left(\mathrm{AuCl}_{4}^{-}: \operatorname{Trp} / 1: 1\right), \lambda_{\mathrm{em}}=486 \mathrm{~nm}\left(\mathrm{AuCl}_{4}^{-}: \operatorname{Trp} / 1: 5\right)$, and $\lambda_{\mathrm{em}}=472 \mathrm{~nm}\left(\mathrm{AuCl}_{4}^{-}: \operatorname{Trp} / 1: 15\right)$. The larger Trp amount causes the decrease of the PL intensities (Figure 1A). This characteristic PL originates from sub-nanometer sized Au nanoclusters (NCs). In the last 8-10 years, the Au NCs, which were synthesized by using template-assisted preparation routes, are in focus of extensive researches. A short summary of only the amino acid-reduced Au NCs is presented in the next chapter.
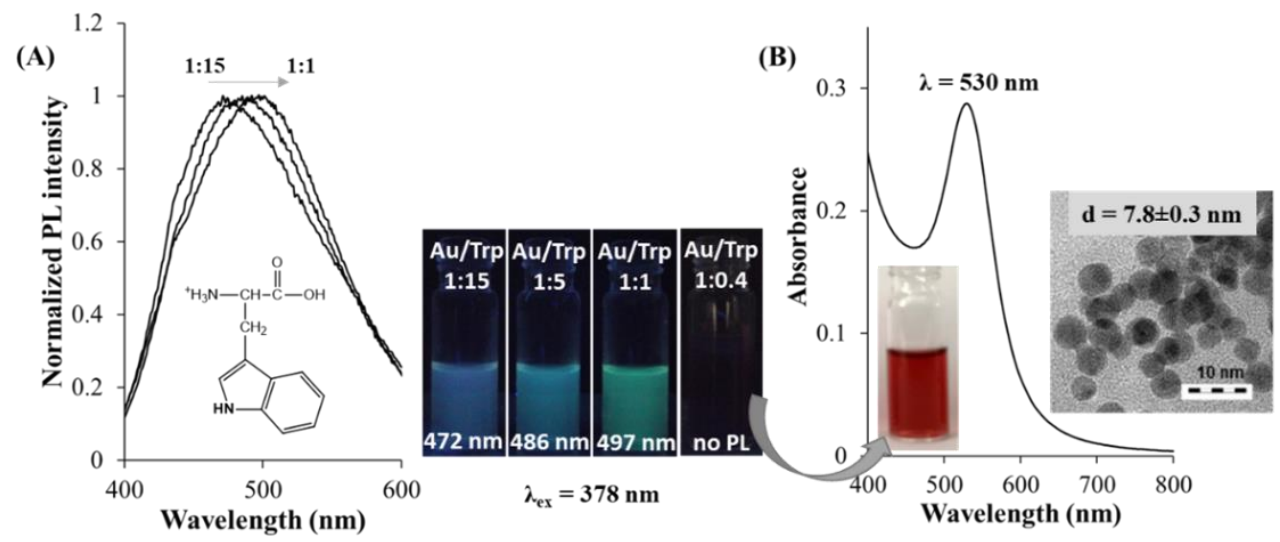

Figure 1. (A) The normalized fluorescence spectra $\left(\lambda_{\mathrm{ex}}=378 \mathrm{~nm}\right)$ of L-tryptophan gold nanoclusters (Trp-Au NCs) with the photos of aqueous dispersions under UV-light. (B) Absorbance spectrum of L-tryptophan gold nanoparticles (Trp-Au NPs) with the HRTEM image. $\mathrm{c}\left(\mathrm{AuCl}_{4}^{-}\right)=1.0 \mathrm{mM}$. Reproduced with permission from [71]. Elsevier, 2017.

\section{Synthetic Routes of Amino Acid-Reduced Fluorescent Au NCs}

Several preparation protocols for Au NCs having sizes less than $2 \mathrm{~nm}$ have been established in the last two decades, including both the "top-down" and "bottom-up" approaches, as Figure 2 summarizes [25,72,73]. 


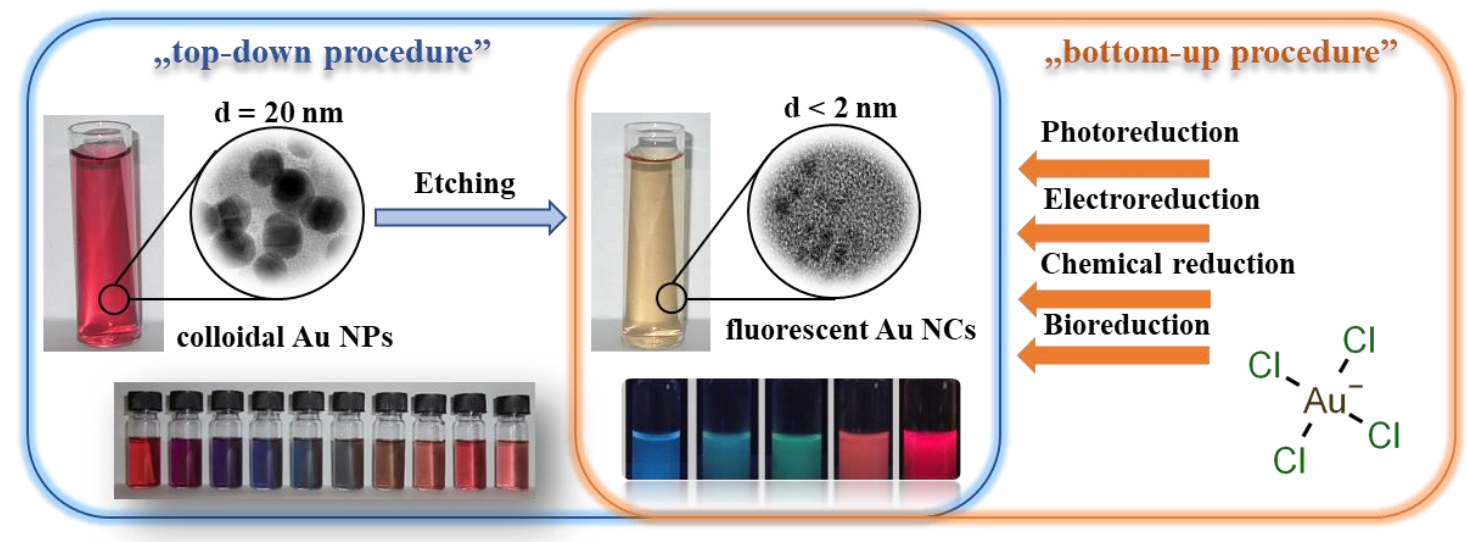

Figure 2. Preparation protocols of Au NCs by "top-down" and "bottom-up" approaches.

For the "top-down" process, the larger colloidal particles undergo so-called "etching" in order to produce smaller clusters, while in case of "bottom-up" methods, the clusters are formed via a reduction of the precursor ions by assembling individual atoms one-by-one [34,74]. The ultra-facile, one-step synthetic processes are in focus of interest, where the execution of the reactions is very convenient, rapid, and mild, exempted from the application of harsh reducing agent, special ambience and media, and high pressure. However, numerous articles were published for the preparation of biocompatible $\mathrm{Au}$ NCs that were synthesized by template-assisted preparation protocols while using proteins and peptides [75,76], polymers [77], DNA [78], dendrimers [79], etc., but only a few publications present the possible applicability of simple amino acids as reducing and stabilizing agents.

In this chapter, we clearly focus on the summary of the amino acid-directed fabrication of $\mathrm{Au}$ NCs having size-and structure-dependent intense PL features [80,81]. Table 1 clearly summarizes the experimental conditions of amino acid-reduced Au NCs and other Au-based nanohybrid structures. As it can be shown, His, Tyr, Pro, Trp, Cys, and Met amino acids were previously studied. Except for Cys and Met having thiol and thioether side chains, blue-emitting $\mathrm{Au}_{3}-\mathrm{Au}_{10} \mathrm{NCs}$ can be synthesized by the spontaneous interaction of $\mathrm{AuCl}_{4}{ }^{-}$with His, Tyr, Pro, and Trp bioligands, depending on the temperature as well as on the ratio of reactant partners. In case of His, $\mathrm{Au}_{10} \mathrm{NCs}$ with relatively high QY(\%) are formed by using $\mathrm{AuCl}_{4}^{-}$:amino acid/1:30 molar ratio at room temperature [82]. As Table 1 summarizes, various research groups fabricated His-reduced $\mathrm{Au}_{10} \mathrm{NCs}$ while using almost the same experimental conditions, where the His-protected Au NCs have been applied for glutathione detection and selective cancer cell imaging [83], while Liu et al. also successfully used the His-Au NCs as ultrasensitive iodide detector system [84]. It can be concluded that, at room temperature, the application of high ligand excess (30-fold excess) results the formation of His-stabilized blue-emitting NCs. Moreover, E. Csapó et al. clearly confirmed that the $\mathrm{pH}$ is also a decisive factor during the synthesis in the case of the His $/ \mathrm{AuCl}_{4}{ }^{-}$system. However, Yang et al. [82] claimed that the emission intensity of the His-stabilized $\mathrm{Au}_{10} \mathrm{NCs}$ was continually decreased with the increase of $\mathrm{pH}$ (from pH $=1.0$ to 13.0) and the extreme acidic condition $(\mathrm{pH}=1-2)$ is optimal for these NCs. In contrast with their results, E. Csapó et al. found that (Figure 3A), if the $\mathrm{pH}$ is smaller than $\mathrm{pH}=5.0$ no emission could be detected, but a characteristic emission peak with continually decreasing intensity to $\mathrm{pH}=12.0$ was evolved at $475 \mathrm{~nm}$ at above $\mathrm{pH}>6$ [71]. The emission maximum values show an interesting correlation with the concentration distribution curves of His. Namely, the emission maximum can be observed in that $\mathrm{pH}$, where the deprotonation of the imidazolium moiety of His eventuates $\left(\mathrm{pK}_{\mathrm{a}}=6.04\right)$ [85]. 
(A)

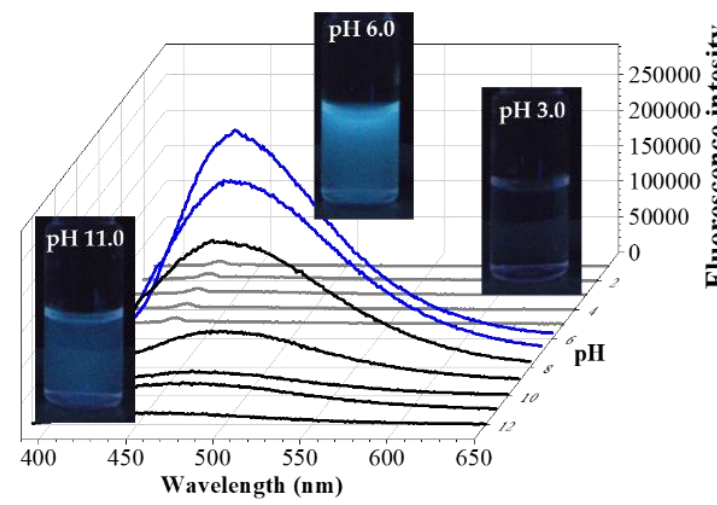

(B)

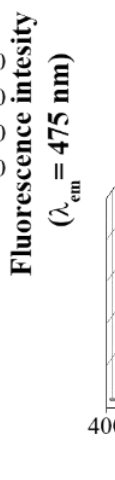

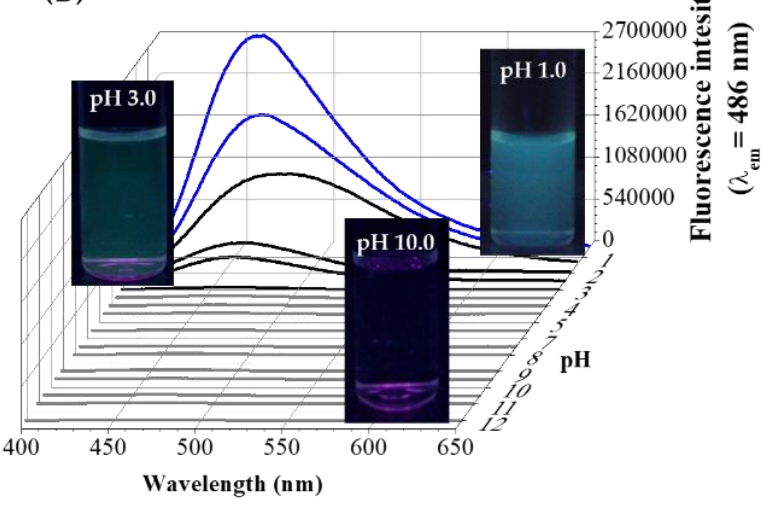

Figure 3. The photoluminescence (c) spectra as a function of the initial $\mathrm{pH}$ of the (A) $\mathrm{AuCl}_{4}{ }^{-}: \mathrm{His} / 1: 30$ and (B) $\mathrm{AuCl}_{4}{ }^{-}: \operatorname{Trp} / 1: 5$ systems with representative photos of the samples under UV-light. $\left(\lambda_{\mathrm{ex}}=378 \mathrm{~nm}\right.$, $\mathrm{c}_{\mathrm{Au}-}=1.00 \mathrm{mM}, \mathrm{T}=37^{\circ} \mathrm{C}$ ). Published in [71], Elsevier, 2017.

Most probably, the primary coordination of the gold ions to the His occurs via the imidazole- $N$ atoms and this aromatic group plays a dominant role in the formation of the fluorescent Au products. Furthermore, it was found that, through the decrease in the concentration of the $\mathrm{AuCl}_{4}{ }^{-}$ions from $\mathrm{c}_{\mathrm{Au}}=2.50 \mathrm{mM}$ to $\mathrm{c}_{\mathrm{Au}}=1.00 \mathrm{mM}$, instead of clusters, the presence of blue-emitting polynuclear $\mathrm{Au}(\mathrm{I})$ complexes having a well-ordered structure is certifiable by several analytical methods [71].

For Tyr, no high ligand excess is necessary, but at room temperature, the spontaneous interaction of the Tyr with $\mathrm{AuCl}_{4}{ }^{-}$ions does not result in the fabrication of Tyr-reduced Au NCs. At higher concentrations $\left(\mathrm{c}_{\mathrm{Au}}=2.50 \mathrm{mM}\right)$, the lower temperature is enough $\left(37^{\circ} \mathrm{C}\right)$, but the boiling condition is essential as the concentration decreases $\left(c_{\mathrm{Au}}=0.07 \mathrm{mM}\right)$. In the case of Pro, which does not contain an aromatic group in the side chain, the use of extreme high ligand excess (more 100-fold excess) and boiling can result in the production of Au NCs having a few gold atoms. For Trp, the $37^{\circ} \mathrm{C}$ and the $100{ }^{\circ} \mathrm{C}$ is optimal for the synthesis using from $1: 1$ to $1: 5 \mathrm{AuCl}_{4}{ }^{-}$:Trp molar ratio at acidic condition, as in Figure 3B, and the previously mentioned tunable optical feature was found, depending on the reactants ratio, which was summarized in chapter 2 in Figure 1A.

Table 1. Experimental conditions of amino acid-reduced Au NCs and Au nanostructures.

\begin{tabular}{|c|c|c|c|c|c|c|c|}
\hline $\begin{array}{l}\text { Amino } \\
\text { Acid }\end{array}$ & $\begin{array}{l}\mathrm{c}_{\mathrm{AuCl}} \\
(\mathrm{mM})\end{array}$ & $\begin{array}{c}\mathrm{AuCl}_{4}{ }^{-}: \text {Amino } \\
\text { Acid Ratio }\end{array}$ & $\mathrm{T}\left({ }^{\circ} \mathrm{C}\right)$ & Product & $\lambda_{\text {ex }}(\mathrm{nm})$ & $\begin{array}{c}\lambda_{\mathrm{em}}(\mathrm{nm}) \\
\mathrm{QY}(\%)\end{array}$ & Ref. \\
\hline His & 2.50 & $1: 30$ & 25 & $\mathrm{Au}_{10} \mathrm{NCs}$ & 386 & $490(8.78 \%)$ & [82] \\
\hline His & 2.50 & $1: 30$ & 25 & $\mathrm{Au}_{10}-\mathrm{Au}_{14} \mathrm{NCs}$ & 370 & 475 (no inf.) & [86] \\
\hline His & 2.50 & $1: 30$ & 25 & $\mathrm{Au}$ NCs * & 386 & 475 (no inf.) & [83] \\
\hline His & 2.50 & $1: 30$ & 25 & $\mathrm{Au} \mathrm{NCs}$ * & 365 & $450(4.60 \%)$ & [84] \\
\hline His & 2.50 & $1: 45$ & 25 & $\mathrm{Au} \mathrm{NCs}$ * & 386 & $498(8.96 \%)$ & [87] \\
\hline Tyr & 0.07 & $1: 0.76$ & 100 & $\mathrm{Au}_{10} \mathrm{NCs}$ & 383 & $498(1.68 \%)$ & [89] \\
\hline Pro & 2.40 & $1: 830$ & 100 & $\mathrm{Au}_{7} \mathrm{NCs}$ & 365 & $440(2.94 \%)$ & [90] \\
\hline \multirow[t]{2}{*}{$\operatorname{Trp}$} & 0.43 & $1: 2.7$ & 100 & $\mathrm{Au}_{8} \mathrm{NCs}$ & 365 & 450 (no inf.) & [91] \\
\hline & 0.50 & $1: 1$ & 37 & $\mathrm{Au}_{3}-\mathrm{Au}_{6} \mathrm{NCs}$ & 378 & $497(1.10 \%)$ & [71] \\
\hline $\operatorname{Trp}$ & 0.50 & $1: 5$ & 37 & $\mathrm{Au}_{3}-\mathrm{Au}_{6} \mathrm{NCs}$ & 378 & $486(1.30 \%)$ & [71] \\
\hline
\end{tabular}

In case of Met and Cys amino acids, which have thiol and thioether moieties in the side chain, the characteristic PL emission band was detected at higher (in the yellow and orange regions between 520-630 nm) wavelengths. However, for Met, the formation of $\mathrm{Au} \mathrm{NCs} \mathrm{having} \mathrm{Au}^{0}$ cores was 
confirmed, but the $\mathrm{pH}$ and the temperature were extremely changed during the two-step preparation route. The spontaneous interaction of thiol-group containing Cys with $\mathrm{AuCl}_{4}{ }^{-}$does not result in clusters. Instead, a periodic $\mathrm{Au}(\mathrm{I}) \mathrm{CPs}$ was identified at $\mathrm{pH}=3.0$ by Söptei et al. measurements [94]. This nanohybrid system has a multilayered construction with $1.3 \mathrm{~nm}$ of distance and show characteristic fluorescence thanks to the (-S-Au(I)-S-Au(I)-S-) n cyclical structure, which was verified by previously published similar $\mathrm{Au}(\mathrm{I})$-thiolate systems $[95,96]$. In conclusion, the application of simple amino acids having aromatic groups (imidazole, indole, benzene) in the side chains dominantly results in the formation of fluorescent Au NCs. In contrast with the larger polypeptides or proteins, which mainly form red-emitting NCs [97], by the utilization of amino acids as reducing agents, only blue-emitting sub-nanometer sized NCs that consist of a few atoms can be synthesized. At lower synthesis temperature (e.g., room temperature), the application of higher ligand excess (ca. 30-fold excess) is advantageous, but, by increasing of the temperature $\left(\sim 40-50^{\circ} \mathrm{C}\right)$, the use of high ligand excess can be reduced. The bioligands like Cys or Cys-containing small peptides, do not produce fluorescent $\mathrm{NCs}$ having $\mathrm{Au}^{0}$, but the formation of partially reduced $-(\mathrm{Au}(\mathrm{I})-\mathrm{SR})_{\mathrm{n}}$ - periodic structures is especially preferred. The preparation possibilities of $-(\mathrm{Au}(\mathrm{I})-\mathrm{SR})_{\mathrm{n}}-$ structures as well as the synthesis routes of thiolate-stabilized $\mathrm{Au} N \mathrm{NP} / \mathrm{NCs}$ and $\mathrm{CPs}$ through the $-(\mathrm{Au}(\mathrm{I})-\mathrm{SR})_{\mathrm{n}}-$ are summarized in the next chapter.

\section{Fabrication Protocols of Thiolate-Protected Au Nanohybrid Systems}

Various publications can be found in the literature, relating to Au nanostructures that are synthesized by the interaction of $\mathrm{AuCl}_{4}{ }^{-}$ions with thiolate molecules as Cys amino acid, peptides having Cys residue or alkyl- and arylthiolates. Depending on the applied fabrication parameters (e.g., chemical structure of the reducing ligand, temperature, molar ratio, $\mathrm{pH}$ ), decisively three different types of gold-thiol nanohybrid systems, such as plasmonic Au NPs or fluorescent Au CPs and $\mathrm{Au}$ NCs, as in Figure 4, can be fabricated. Nevertheless, the presence of similar bond (e.g., covalent bond) between the gold and the sulphur atom(s) of the applied bioligands was confirmed for all the nanostructures.

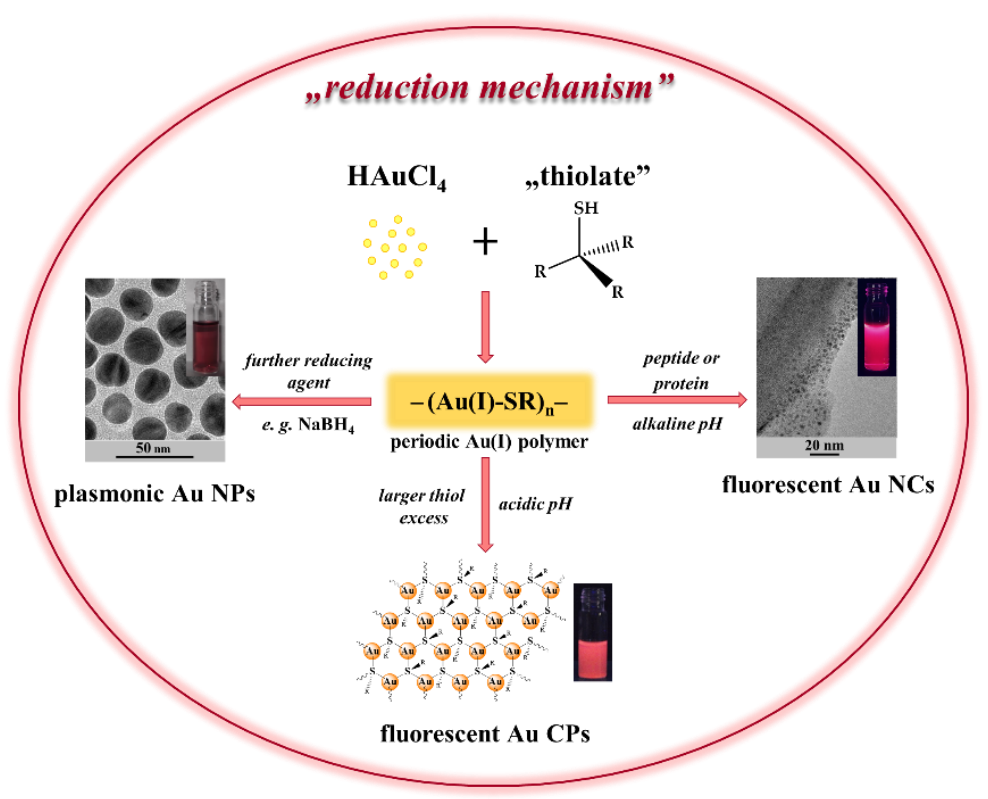

Figure 4. Schematic illustration on the formation mechanisms of different Au nanohybrid systems via interaction of tetrachloroaurate(III) ions with thiolate ligands.

As mentioned in chapter (2.), one of the most commonly used synthesis is the two-phase Brust method for the formation of thiol-protected plasmonic Au NPs [11]. To simplify this method, C. K. Yee et al. developed a protocol, where only tetrahydrofuran was applied as individual solvent [98]. In both 
methods, several functionalized colloidal particles have been synthesized, which are functionalized by different alkyl- or arylthiols. The size of these Au NPs can be tuned by the molar ratio of the $\mathrm{AuCl}_{4}{ }^{-}$:thiol-containing molecule, but the one-phase synthesis eventuates larger plasmonic particles [99]. For the exact understanding of these syntheses, Perala and Kumar presented a new synthetic route [100], where the formation of the particle consists of a two-step reduction mechanism, as demonstrated by the Equations (1) and (2).

$$
\begin{gathered}
\mathrm{AuCl}_{4}{ }^{-}+4 \mathrm{RSH} \rightarrow-(\mathrm{Au}(\mathrm{I})-\mathrm{SR})_{\mathrm{n}^{-}}+\mathrm{RSSR}+4 \mathrm{Cl}^{-}+3 \mathrm{H}^{+} \\
-(\mathrm{Au}(\mathrm{I})-\mathrm{SR})_{\mathrm{n}^{-}}+\mathrm{BH}_{4}{ }^{-}+\mathrm{RSH}+\mathrm{RSSR} \rightarrow \mathrm{Au}_{\mathrm{x}}(\mathrm{SR})_{\mathrm{y}}
\end{gathered}
$$

Based on the proposed mechanism, the first two equivalents alkyl- or arylthiol partially reduces the $\mathrm{AuCl}_{4}{ }^{-}$ions to $\mathrm{Au}(\mathrm{I})$, while next two equivalents involve in the formation of a periodic $-(\mathrm{Au}(\mathrm{I})-\mathrm{SR})_{\mathrm{n}}-$ polymer [101]. The final $\mathrm{Au}(\mathrm{I}) \rightarrow \mathrm{Au}^{0}$ reduction is carried out by a borohydride salt, which results in the formation of $\mathrm{Au}_{\mathrm{x}}(\mathrm{SR})_{\mathrm{y}}$. After reduction, the nucleation, as well as the crystal growth and the particle functionalization, are simultaneously occurred.

As it can be seen, the formation of thiol-protected Au nanohybrid systems occurs through the appearance of a periodic - $(\mathrm{Au}(\mathrm{I})-\mathrm{SR})_{\mathrm{n}}$ - polymer structure. These periodic polymers can simply be further transformed into new gold-containing products having different structure and optical properties (Figure 4). (i) On one hand, the utilization of strong reducing agents (e.g., $\mathrm{NaBH}_{4}$ ) results in colloidal Au NPs having plasmonic feature; (ii) by the application of a large excess of bioligand having thiol group in the side chain, such as Cys amino acid [40] or glutathione (GSH) tripeptide [102], the formation of Au CPs structures, including self-assembly structure at acidic conditions, is preferred; and, (iii) for the presence of peptide or protein reducing agents excess, fluorescent Au NCs can be synthesized.

These mentioned nanostructures (especially the NCs and CPs) possess intense structure-dependent PL mostly in the orange and red visible or the near infrared (NIR) region. The hybrid electronic states are formed between the sulphur atoms of the ligands and the gold atoms, which results in the emission from the sp to $\mathrm{d}$ band transitions [81]. These hybrid bands are below the $\mathrm{d}$ band states of $\mathrm{Au}(\mathrm{I})$ ions and the excitation wavelength-dependent fluorescence lifetime suggests that the triplet and singlet states are degenerated. In contrast, the hybrid orbitals are above the $\mathrm{d}$ band states of gold in case of NIR emission and the microsecond fluorescence lifetime refers to the strong involvement of the $\mathrm{Au}(\mathrm{I})-\mathrm{S}$ charge transfer in the emission process (Figure 5A,B). In this chapter, the preparation protocols of $\mathrm{Au}$ $\mathrm{CPs}$ as well as the Au NCs systems were mainly interpreted.

In the case of earlier reports, the $\mathrm{pH}$ was not really regulated in the initial stage of the "green" synthesis as well as quite small GSH, Cys, or another thiolates excess was applied. Whereupon, $\mathrm{NaBH}_{4}$ was usually necessary to supplement the reduction process. As a result of the simple reaction of GSH and $\mathrm{HAuCl}_{4}$, T. G. Schaaff and R. L. Whetten identified three different GSH-Au(I) polymers. The $\mathrm{AuCl}_{4}^{-}: \mathrm{GSH} / 1: 3$ molar ratio, ca. $0.3 \mathrm{mM}$ of $\mathrm{HAuCl}_{4}$ concentration and ten-fold excess of $\mathrm{NaBH}_{4}$ in methanol:water solvent mixture were applied at room temperature, which prevent the polymer from the uncontrolled reduction [103]. The separation of the dark brown products was carried out by polyacrylamide gel filtration (PAGE) and the average sizes of the polymers were 4.3, 5.6, and 8.2 kDa. These nanohybrid systems show strong structure-dependent optical properties in the NIR, visible and UV-region, while the unseparated mixture nor. Y. Negeshi et al. also investigated the effect of the GSH and homo-GSH on the $\mathrm{HAuCl}_{4}$ in two articles. In contrast to the previous result, $\mathrm{AuCl}_{4}{ }^{-}: \mathrm{GSH} / 1: 4 \mathrm{molar}$ ratio and $4 \mathrm{mM}$ of tetrachloroaurate(III) concentration were adjusted with a large excess of $\mathrm{NaBH}_{4}$ at $0{ }^{\circ} \mathrm{C}[104,105]$. The identification of the dark-brown powder was accomplished after the PAGE and ultracentrifugation. The nine different $\mathrm{Au}(\mathrm{I})$-polymer structures were recognized by Electrospray Ionization Mass Spectrometry (ESI-MS), optical absorption, and PL spectroscopy (Figure 5C). 
(A)

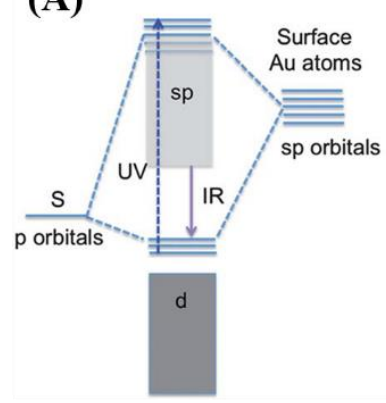

(B)

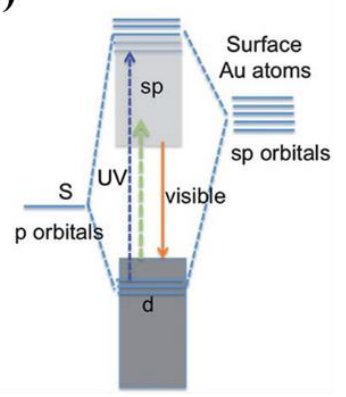

(C)

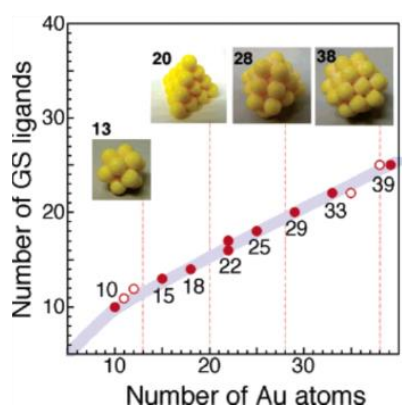

Figure 5. The scheme of the sp and d transitions in case of the (A) NIR-and (B) visible-emitting thiolate-protected Au nanohybrid systems. Reproduced with permission from [81], RSC, 2012. (C) The relationship between the Au atoms and glutathione (GSH) ligands in the most dominant (๑) and secondary (o) products. Reproduced with permission from [105], ACS, 2005.

This article presented firstly that, the smaller structures have rather polymeric properties such as the larger emission wavelength and larger binding energy $\left(\mathrm{Au} 4 \mathrm{f}_{7 / 2} \sim 85 \mathrm{eV}\right)$, which refers to the decisive presence of $\mathrm{Au}(\mathrm{I})$. On the other hand, the systems having larger sizes show cluster-like characteristics with higher emission energy and the binding energy was detected at $84-85 \mathrm{eV}$. Thereby, the relationship was clearly pointed out between the size, the structure, and the optical behavior of the Au nanohybrid systems.

Neglecting of further reducing agents, R. E. Bachman et al. applied a phenylthiolate to synthesize a fluorescent and self-assembly gold(I) polymeric structure via decomposition of isonitrilegold(I) complex [106]. For the formation of supramolecular system, the dimer units aggregated in an antiparallel fashion at $255^{\circ} \mathrm{C}$, which can be described as a "crinkled tape" motif. It has strong PL in the red region at $\lambda_{\mathrm{em}}=660 \mathrm{~nm}$ due to the weak aurophilic interaction in the supramolecular system. I. Odriozola et al. also examined the direct interaction of GSH and $\mathrm{AuCl}_{4}{ }^{-}$while using 1:3/gold: ligand molar ratio without the utilization of any further reducing chemicals at room temperature [107]. In their publication, the sol-gel transition was demonstrated, by which the prominent role of the $\mathrm{pH}$ on the gold(I)-thiolate structure was discussed. The possible chemical structures of the sol and the gel state were also suggested. H. Nie et al. 3-mercaptopropionic acid, thioglycolic acid, 1-thiogliycerol, and GSH were used to synthesize Au CPs with metal ion: ligand/1:1 stoichiometry [108]. As several CPs have great UV-Vis absorptions that originate from the ligand to metal and the metal-centered charge transfers, thereby the prepared nanohybrids are suitable for the in-situ checking the self-assembly of thiol-Au(I) $\mathrm{CPs}$. The synergic effects of the weak interactions were identified with applying different analytical methods (e.g., time-resolved UV-Vis spectrophotometry, HRTEM, X-ray diffraction/XRD, and X-ray photoelectron spectroscopy/XPS). Consequently, it has been proved that the H-bonding, aurophilic and static interactions, and coordination bonding facilitate the evolution of the order structure for $\mathrm{Au}(\mathrm{I}) \mathrm{CPs}$. $\mathrm{C}$. Lavenn et al. also used phenylthiolate to prepare Au CPs by the development of a hydrothermal method at $120^{\circ} \mathrm{C}$ [41]. The formed double helical Au CPs are also stabilized by $\mathrm{C}-\mathrm{H} \cdot \pi$ and aurophilic bonds. The product has red emission $\left(\lambda_{\mathrm{em}}=684 \mathrm{~nm}\right)$ and great quantum yield $(\sim 5 \%)$. Furthermore, a thermally induced crystallization was presented in solid-state, which rarely occurred in gold(I) polymers. A. T. Royappa et al. applied two different water soluble ethanol-based thiolate molecules to produce of $\mathrm{Au}(\mathrm{I}) \mathrm{CPs}$ while using $\mathrm{AuCl}_{4}^{-}:$thiol/1:3 molar ratios [109]. The synthesis had a nearly quantitative yield and an amorphous colored gel-like solid was identified as periodic coordination polymer structure, which contains significant aurophilic interactions between the gold atoms.

Besides the previously mentioned, mainly thiolate-based Au CPs, the possible use of biocompatible amino acid Cys is in the focus of interest, especially in the last five years. P. S. Capellari et al. synthesized of $\sim 0.6 \mathrm{~nm}$ ultra-small Cys-capped plasmonic Au NPs by precise growth controlling in mild conditions while using $\mathrm{pH}$ switching [110]. For understanding the formation mechanism, both acidic and alkaline conditions were examined. The applied molar ratio was ca. $\mathrm{AuCl}_{4}^{-}: \mathrm{Cys} / 1: 1$ with $5 \mathrm{mM}$ of 
$\mathrm{HAuCl}_{4}$ concentration at room temperature. Thanks to their experiments, two very stable polymeric gold(I)-thiolate structure were discerned at the two edges of the $\mathrm{pH}$ range and a rather reactive $\mathrm{pH}$ interval was identified between $4<\mathrm{pH}<9$. Based on several X-ray analytical methods, the structure of the Cys- $\mathrm{Au}(\mathrm{I})$ polymer show strong $\mathrm{pH}$-dependence due to the zwitterionic nature of the Cys. The reactive state was suitable for controlled synthesizing of the plasmonic particle from the stable polymeric structures by $\mathrm{pH}$ switching and the adding of $\mathrm{NaBH}_{4}$. For the structural characterization, $\mathrm{B}$. Söptei et al. examined the pale-yellow solid powder by small- and wide-angle X-ray scattering (SWAXS), which was formed by the direct reduction process between the Cys and $\mathrm{AuCl}_{4}{ }^{-}$. For the preparation, $\mathrm{AuCl}_{4}{ }^{-}: \mathrm{Cys} / 1: 10$ molar ratio with $5 \mathrm{mM}$ of gold concentration and three different temperature were tested without any regulation of the $\mathrm{pH}$ [94]. In their publication, a periodic lamellar structure was presented based on the SWAXS measurements, where the average distance of the lamellas was $1.3 \mathrm{~nm}$. Beside these, the primary coordination bonds were defined by FT-IR spectroscopy. In the IR spectrum of the lamellar structure, the band corresponding to the S-H vibrations was disappeared, while a band was observed at the $\mathrm{C}=\mathrm{O}$ stretching vibrations. These referred to the Au-S bond in the polymer structure, which were stabilized by strong H-bonds and electrostatic interactions due to the zwitterionic behavior of the Cys amino acid. E. Csapó et al. also examined the spontaneous reaction of the Cys and two cysteine-containing peptides with $\mathrm{AuCl}_{4}{ }^{-}$ions while using $1.0 \mathrm{mM}$ of gold concentration at $37^{\circ} \mathrm{C}$ in aqueous medium [93]. Depending on the applied $\mathrm{pH}$, the molar ratios and the chemical structure of the Cys and Cys-containing peptides (Cys-Trp, GSH), diverse nanohybrid systems were formed, as in Figure 6. For understanding the ligand-dependent structures of these produced systems, two-dimensional (2D) techniques (surface plasmon resonance and quartz crystal microbalance) were additionally applied. In both cases, orange-emitting products $\left(\lambda_{\mathrm{em}}=620\right.$ and $590 \mathrm{~nm}$ ) were confirmed while using $\mathrm{AuCl}_{4}^{-}: \mathrm{Cys} / 1: 10$ and $\mathrm{AuCl}_{4}^{-}: \mathrm{GSH} / 1: 15$ ratios, respectively. Under acidic conditions ( $\mathrm{pH} 3.0$ ), the coordination polymers were identified and the lamellar architecture with $1.3 \mathrm{~nm}$ distance of the Cys-Au(I) CPs is also certified by XRD. Nevertheless, the ordered structure of GSH-Au(I) CPs was not verified, probably for the larger space-filling of the side chain. Under basic conditions, the orange emission was not observed in the GSH-Au system, but a new blue emission band was involved at $445 \mathrm{~nm}$. The XPS studies of this system supposed the formation of ultra-small $\mathrm{Au}^{0}$ clusters. In contrast of Cys, the redox potential of GSH shows a strong $\mathrm{pH}$-dependent property, thus the tripeptide has stronger reduction capability against the $\mathrm{Au}(\mathrm{III})$ ions. Next to the redox feature of the GSH, the hydrolytic process of the aurate(III) ions also influences the structure of final gold products. The presence of $\mathrm{AuCl}_{4}{ }^{-}$is dominant between $\mathrm{pH}=1-3$, but, at basic conditions, the appearance of various hydroxo species (e.g., $\mathrm{AuCl}(\mathrm{OH})_{3}{ }^{-}$or $\left.\mathrm{Au}(\mathrm{OH})_{4}{ }^{-}\right)$is exclusive.

The amine and thiol-containing dipeptide, named cysteinyl-tryptophan (Cys-Trp), showed mainly amino acid behavior against the $\mathrm{AuCl}_{4}^{-}$. Depending on the applied ligand amount, the optical properties of the formed gold systems can be tuned. With a small quantity of the Cys-Trp (1:0.5/ $\mathrm{AuCl}_{4}{ }^{-}$:ligand ratio) under basic conditions, plasmonic Au NPs were synthesized with ca. 8-9 nm. In contrast, while using 20-fold dipeptide excess two-coordinated $\mathrm{Au}(\mathrm{I})$-complexes with blue emission $\left(\lambda_{\mathrm{em}}=470 \mathrm{~nm}\right)$ were identified by the MS techniques. The supramolecular self-assembly of these complexes was not observed, presumably also due to the large size of the ligand. The thioether Met amino acid was used for synthesizing Au NCs by H. H. Deng and co-workers [92]. For the preparation of Met-Au NCs, extreme large Met excess and a two-step thermostated reaction were applied in alkaline medium. The identified cluster shows yellow emission at $530 \mathrm{~nm}$ and the quantum yield was $2.9 \%$ with two dominant fluorescence lifetimes (181 ns and $1.6 \mu \mathrm{s})$. The XPS spectrum suggested that the cluster decisively built up from $\mathrm{Au}^{0}$. Based on the FT-IR studies, the functional groups of $-\mathrm{NH}_{2}$ and $-\mathrm{COOH}$ take part in the formation of the coordinative bonds on the cluster surface, but not on the sulphur atom. 


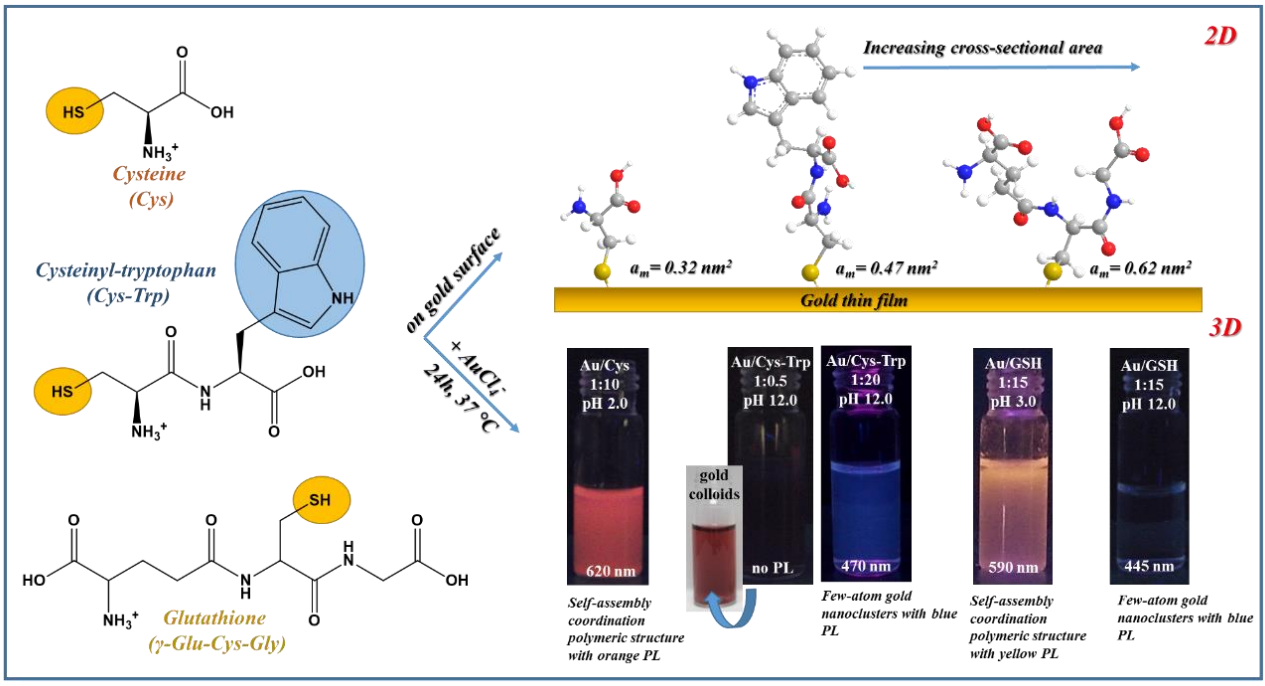

Figure 6. Schematic illustration of the binding of Cys and Cys-containing peptides on gold surface with the corresponding cross-sectional area (above) and the formation of Cys-, Cys-Trp-, and GSH-reduced $\mathrm{Au}$ NPs, $\mathrm{Au}$ NCs, and $\mathrm{Au} \mathrm{CPs}$ by spontaneous interaction of the mentioned molecules with $\mathrm{AuCl}_{4}{ }^{-}$ with some representative images. Published in [93], Elsevier, 2016.

As it can be seen, the application of simple (bio)thiolates as simultaneous reducing and stabilizing agent results $\mathrm{Au}(\mathrm{I})$-containing periodic polymer products in most cases. For the synthesis of thiol-reduced Au NCs, either other reducing agents (e.g., borohydride salts) or proteins are usually required. Forasmuch, this article is limited to detailed descriptions of the direct interaction between small amines and thiols, only the brief introduction of the mechanism of the protein-tetrachloroaurate(III) reaction is as follows, because the peptides can be considered as large-sized biocompatible thiolates and amines. Several articles can be found on the syntheses of protein-stabilized Au NCs while using the BSA [111-113], HSA [114,115], LYZ [116-120], trypsin [121], pepsin [122], or immunoglobulin [76]. The typically red-emitting cluster synthesis is carried out under basic conditions ( $\sim \mathrm{pH} 12)$ and 10-20-fold protein excess is applied at ca. $40{ }^{\circ} \mathrm{C}$ for $24 \mathrm{~h}$. The purification can be done by dialysis or PAGE techniques. The synthesized $\mathrm{Au}_{25} \mathrm{NCs}$ contain a core having icosahedral $\mathrm{Au}_{13}$, which are covered by an $\mathrm{Au}_{22}$ shell and they are stabilized by 18 thiolate ligands based on the X-ray crystallographic analysis [123]. Nevertheless, the general accepted mechanism of the cluster formation is the follows. The complete reduction of the $\mathrm{Au}(\mathrm{III})$ to $\mathrm{Au}^{0}$ also occurred via a precious presented two-steps process. The primary $\mathrm{Au}(\mathrm{III}) \rightarrow \mathrm{Au}(\mathrm{I})$ progress occurs along the side chain of Trp and Tyr residues. Following a "chain migration", the gold(I) ions are coordinated by the sulphur-containing molecules, where the further reduction is realized by the nearby and suitable amino acids. On one hand, the used extreme basic conditions serve to improve the reduction capability of the Tyr and Trp amino acids. On the other hand, the unfolding of the protein chain is also contributed by applying of alkaline medium, which facilitates easier migration of the partially reduced metal ions along the chain. Based on the above considerations, the presence of the adequate Tyr and Trp beside the thiol-containing amino acids is definitely an important criterion for the success of Au NCs syntheses [124-126]. It can be regarded that the proteins are a great bridge between the biocompatible amine and thiolate ligands.

\section{Conclusions}

The gold nanoparticles, the ultra-small Au nanoclusters consisting a few or few tens of gold atoms, and the Au-containing self-assembled coordination polymers are in focus of extensive researches thanks to their several excellent properties. Due to the low toxicity as well as their unique, structure-dependent optical feature, they can be used in several fields of medical applications, like as the controlled drug delivery, cancer treatment, fluorescence imaging, diagnostic, and sensing. One of the most 
important requirements in these medical utilizations is the biocompatibility and the synthesis of these nanostructures under mild reaction conditions in aqueous medium using biocompatible capping agents and avoiding the harsh reducing agents or organic solvents, etc. Based on these expectations, in this review we decisively focused on the short summary of the possible synthetic routes of the formation of colloidal Au NPs, Au NCs, and Au CPs via template-assisted preparation protocol while using amino acids and thiolates as reducing and stabilizing molecules.

For amino acids we can conclude that, almost all amino acids, except Cys, are able to reduce the precursor $\mathrm{AuCl}_{4}{ }^{-}$ions at mostly high temperature $\left(\mathrm{T}=50-100{ }^{\circ} \mathrm{C}\right)$, and the formation of stable colloidal Au NPs is preferred. Besides the higher temperature, the high pressure, as well as the extra conditions, like alkaline medium, the high ligand excess or the application of UV light further facilitate the appearance of Au NPs, having sizes larger than $2 \mathrm{~nm}$. In the case of fluorescent amino acids-reduced Au NCs, only the possible utilization of His, Trp, Pro, and Tyr having aromatic residues in the side chain was confirmed to date. At lower synthesis temperature (e.g., room temperature), the application of higher ligand excess (ca. 30-fold excess) is advantageous, but, by increasing of the temperature $\left(\sim 40-50{ }^{\circ} \mathrm{C}\right)$, the use of high ligand excess can be reduced.

The Cys or Cys-containing peptides do not produce fluorescent NCs, but the formation of $\mathrm{Au}(\mathrm{I})$-containing polymers having an ordered structure is especially preferred. The preparation possibilities of these structures through the periodic -(Au(I)-SR)n- as well as the characteristic features of thiolate-stabilized Au NPs/NCs and CPs were also summarized. As presented, the detailed examination of the relationship between the reaction conditions and the optical/structural features of the formed Au-containing nanohybrid systems is extremely important for future applications. Due to the effective PL quenching of Au NCs and Au CPs or the LSPR phenomena of Au NPs, these nanostructures are potential candidates for Photodynamic therapy (PDT), Photothermal therapy (PTT), and X-ray imaging. Moreover, these nanosized noble metal-based nanohybrid structures play a decisive role as possible nanosized controlled drug delivery systems in pharmaceutical applications. Moreover, the sub-nanometer sized fluorescent NCs are excellent nanosensors for rapid and selective detection of essential (Fe(III), $\mathrm{Cu}(\mathrm{II})$ ) and toxic $(\mathrm{Hg}(\mathrm{II}), \mathrm{Cd}(\mathrm{II}))$ metal ions, anions (e.g., $\mathrm{CN}^{-}$), or biological molecules (e.g., glucose, folic acid, glutathione, toxins, drugs, etc.)

Author Contributions: Conceptualization, E.C. and D.U.; writing-original draft preparation, D.U. and E.C.; writing-review and editing, E.C. and D.U.; supervision, I.D.

Funding: This research was supported by the National Research, Development and Innovation Office-NKFIH through the project GINOP-2.3.2-15-2016-00038 and FK131446 and FK132067. This paper was supported by the János Bolyai Research Scholarship of the Hungarian Academy of Sciences (E. Csapó) and UNKP-19-4-SZTE-57 New National Excellence Program of the Ministry of Human Capacities (E. Csapó). The Ministry of Human Capacities, Hungary grant TUDFO/47138-1/2019-ITM is also acknowledged.

Conflicts of Interest: The authors declare no conflict of interest.

\section{References}

1. Chen, M.; Yin, M. Design and development of fluorescent nanostructures for bioimaging. Prog. Polym. Sci. 2014, 39, 365-395. [CrossRef]

2. Zaitsev, S.Y.; Solovyeva, D.O. Supramolecular nanostructures based on bacterial reaction center proteins and quantum dots. Adv. Colloid Interface Sci. 2015, 218, 34-47. [CrossRef]

3. Pérez-Juste, J.; Pastoriza-Santos, I.; Liz-Marzán, L.M.; Mulvaney, P. Gold nanorods: Synthesis, characterization and applications. Coord. Chem. Rev. 2005, 249, 1870-1901. [CrossRef]

4. Dykman, L.; Khlebtsov, N. Gold nanoparticles in biomedical applications: Recent advances and perspectives. Chem. Soc. Rev. 2012, 41, 2256-2282. [CrossRef]

5. Faraday, M. The Bakerian Lecture: Experimental Relations of Gold (and Other Metals) to Light. Philos. Trans. R. Soc. Lond. 1857, 147, 145-181. [CrossRef]

6. Creighton, J.A.; Eadon, D.G. Ultraviolet-visible absorption spectra of the colloidal metallic elements. J. Chem. Soc. Faraday Trans. 1991, 87, 3881-3891. [CrossRef] 
7. Huang, X.; El-Sayed, M.A. Gold nanoparticles: Optical properties and implementations in cancer diagnosis and photothermal therapy. J. Adv. Res. 2010, 1, 13-28. [CrossRef]

8. Mafuné, F.; Kohno, J.Y.; Takeda, Y.; Kondow, T. Full physical preparation of size-selected gold nanoparticles in solution: Laser ablation and laser-induced size control. J. Phys. Chem. B 2002, 106, 7575-7577. [CrossRef]

9. Freitas de Freitas, L.; Varca, G.; dos Santos Batista, J.; Benévolo Lugão, A. An Overview of the Synthesis of Gold Nanoparticles Using Radiation Technologies. Nanomaterials 2018, 8, 939. [CrossRef]

10. Panigrahi, S.; Kundu, S.; Ghosh, S.K.; Nath, S.; Pal, T. General method of synthesis for metal nanoparticles. J. Nanoparticle Res. 2004, 6, 411-414. [CrossRef]

11. Brust, M.; Walker, M.; Bethell, D.; Schiffrin, D.J.; Whyman, R. Synthesis of thiol-derivatised gold nanoparticles in a two-phase Liquid-Liquid system. J. Chem. Soc. Chem. Commun. 1994, 801-802. [CrossRef]

12. Kuzmann, E.; Csapó, E.; Stichleutner, S.; Garg, V.K.; de Oliveira, A.C.; da Silva, S.W.; Sing, L.H.; Pati, S.S.; Guimaraes, E.M.; Lengyel, A.; et al. Fine structure of gold nanoparticles stabilized by buthyldithiol: Species identified by Mössbauer spectroscopy. Colloids Surf. A Physicochem. Eng. Asp. 2016, 504, 260-266. [CrossRef]

13. Turkevich, J.; Stevenson, P.C.; Hillier, J. A study of the nucleation and growth processes in the synthesis of colloidal gold. Discuss. Faraday Soc. 1951, 11, 55. [CrossRef]

14. Majzik, A.; Patakfalvi, R.; Hornok, V.; Dékány, I. Growing and stability of gold nanoparticles and their functionalization by cysteine. Gold Bull. 2009, 42, 113-123. [CrossRef]

15. Csapó, E.; Oszkó, A.; Varga, E.; Juhász, Á.; Buzás, N.; Kőrösi, L.; Majzik, A.; Dékány, I. Synthesis and characterization of Ag/Au alloy and core(Ag)-shell(Au) nanoparticles. Colloids Surf. A Physicochem. Eng. Asp. 2012, 415, 281-287. [CrossRef]

16. Xu, F.; Zhang, Q.; Gao, Z. Simple one-step synthesis of gold nanoparticles with controlled size using cationic Gemini surfactants as ligands: Effect of the variations in concentrations and tail lengths. Colloids Surf. A Physicochem. Eng. Asp. 2013, 417, 201-210. [CrossRef]

17. Bali, K.; Sáfrán, G.; Pécz, B.; Mészáros, R. Preparation of Gold Nanocomposites with Tunable Charge and Hydrophobicity via the Application of Polymer/Surfactant Complexation. ACS Omega 2017, 2, 8709-8716. [CrossRef]

18. Polavarapu, L.; Xu, Q.H. A single-step synthesis of gold nanochains using an amino acid as a capping agent and characterization of their optical properties. Nanotechnology 2008, 19, 075601. [CrossRef]

19. Slocik, J.M.; Stone, M.O.; Naik, R.R. Synthesis of gold nanoparticles using multifunctional peptides. Small 2005, 1, 1048-1052. [CrossRef]

20. Francois, T.; Onani, M.; Madiehe, A.; Meyer, M. Aqueous soluble gold nanoparticle synthesis using polyethyleneimine and reduced glutathione. Int. J. Mater. Res. 2014, 105, 1025-1037. [CrossRef]

21. Gericke, M.; Pinches, A. Microbial production of gold nanoparticles. Gold Bull. 2006, 39, 22-28. [CrossRef]

22. Sharma, N.; Pinnaka, A.K.; Raje, M.; FNU, A.; Bhattacharyya, M.S.; Choudhury, A.R. Exploitation of marine bacteria for production of gold nanoparticles. Microb. Cell Fact. 2012, 11, 1. [CrossRef]

23. Li, J.; Li, Q.; Ma, X.; Tian, B.; Li, T.; Yu, J.; Dai, S.; Weng, Y.; Hua, Y. Biosynthesis of gold nanoparticles by the extreme bacterium Deinococcus radiodurans and an evaluation of their antibacterial properties. Int. J. Nanomed. 2016, 11, 5931-5944. [CrossRef]

24. Chen, L.Y.Y.; Wang, C.W.W.; Yuan, Z.; Chang, H.T.T. Fluorescent gold nanoclusters: Recent advances in sensing and imaging. Anal. Chem. 2015, 87, 216-229. [CrossRef]

25. Jin, R.; Zeng, C.; Zhou, M.; Chen, Y. Atomically Precise Colloidal Metal Nanoclusters and Nanoparticles: Fundamentals and Opportunities. Chem. Rev. 2016, 116, 10346-10413. [CrossRef]

26. Kaur, N.; Aditya, R.N.; Singh, A.; Kuo, T.R. Biomedical Applications for Gold Nanoclusters: Recent Developments and Future Perspectives. Nanoscale Res. Lett. 2018, 13, 302. [CrossRef]

27. Qu, X.; Li, Y.; Li, L.; Wang, Y.; Liang, J.; Liang, J. Fluorescent Gold Nanoclusters: Synthesis and Recent Biological Application. J. Nanomater. 2015, 2015, 1-23. [CrossRef]

28. Yin, X.; Chen, S.; Wu, A. Green chemistry synthesis of gold nanoparticles using lactic acid as a reducing agent. Micro Nano Lett. 2010, 5, 270. [CrossRef]

29. Sharma, R.K.; Gulati, S.; Mehta, S. Preparation of gold nanoparticles using tea: A green chemistry experiment. J. Chem. Educ. 2012, 89, 1316-1318. [CrossRef]

30. Sujitha, M.V.; Kannan, S. Green synthesis of gold nanoparticles using Citrus fruits (Citrus limon, Citrus reticulata and Citrus sinensis) aqueous extract and its characterization. Spectrochim. Acta Part A Mol. Biomol. Spectrosc. 2013, 102, 15-23. [CrossRef] 
31. Antoine, R.; Bertorelle, F.; Broyer, M.; Compagnon, I.; Dugourd, P.; Kulesza, A.; Mitrič, R.; Bonačić-Koutecký, V. Gas-phase synthesis and intense visible absorption of tryptophangold cations. Angew. Chem. Int. Ed. 2009, 48, 7829-7832. [CrossRef]

32. Le Guével, X.; Daum, N.; Schneider, M. Synthesis and characterization of human transferrin-stabilized gold nanoclusters. Nanotechnology 2011, 22, 275103. [CrossRef]

33. Liu, C.L.; Wu, H.T.; Hsiao, Y.H.; Lai, C.W.; Shih, C.W.; Peng, Y.K.; Tang, K.C.; Chang, H.W.; Chien, Y.C.; Hsiao, J.K.; et al. Insulin-directed synthesis of fluorescent gold nanoclusters: Preservation of insulin bioactivity and versatility in cell imaging. Angew. Chem. Int. Ed. 2011, 50, 7056-7060. [CrossRef]

34. Duan, H.; Nie, S. Etching Colloidal Gold Nanocrystals with Hyperbranched and Multivalent Polymers: A New Route to Fluorescent and Water-Soluble Atomic Clusters. J. Am. Chem. Soc. 2007, 129, 2412-2413. [CrossRef]

35. Sun, X.; Dong, S.; Wang, E. One-step preparation and characterization of poly(propyleneimine) dendrimer-protected silver nanoclusters. Macromolecules 2004, 37, 7105-7108. [CrossRef]

36. Zhang, Y.; Jiang, H.; Ge, W.; Li, Q.; Wang, X. Cytidine-directed rapid synthesis of water-soluble and highly yellow fluorescent bimetallic AuAg nanoclusters. Langmuir 2014, 30, 10910-10917. [CrossRef]

37. Zhang, Y.; Jiang, H.; Wang, X. Cytidine-stabilized gold nanocluster as a fluorescence turn-on and turn-off probe for dual functional detection of $\mathrm{Ag}^{+}$and $\mathrm{Hg}^{2+}$. Anal. Chim. Acta 2015, 870, 1-7. [CrossRef]

38. Ahn, J.K.; Kim, H.Y.; Baek, S.; Park, H.G. A new s-adenosylhomocysteine hydrolase-linked method for adenosine detection based on DNA-templated fluorescent $\mathrm{Cu} / \mathrm{Ag}$ nanoclusters. Biosens. Bioelectron. 2017, 93, 330-334. [CrossRef]

39. Ungor, D.; Csapó, E.; Kismárton, B.; Juhász, A.; Dékány, I. Nucleotide-directed syntheses of gold nanohybrid systems with structure-dependent optical features: Selective fluorescence sensing of $\mathrm{Fe}^{3+}$ ions. Colloids Surf. B Biointerfaces 2017, 155, 135-141. [CrossRef]

40. Nafady, A.; Afridi, H.I.; Sara, S.; Shah, A.; Niaz, A. Direct synthesis and stabilization of Bi-sized cysteine-derived gold nanoparticles: Reduction catalyst for methylene blue. J. Iran. Chem. Soc. 2011, 8, S34-S43. [CrossRef]

41. Lavenn, C.; Okhrimenko, L.; Guillou, N.; Monge, M.; Ledoux, G.; Dujardin, C.; Chiriac, R.; Fateeva, A.; Demessence, A. A luminescent double helical gold(I)-thiophenolate coordination polymer obtained by hydrothermal synthesis or by thermal solid-state amorphous-to-crystalline isomerization. J. Mater. Chem. C 2015, 3, 4115-4125. [CrossRef]

42. Deák, A.; Jobbágy, C.; Marsi, G.; Molnár, M.; Szakács, Z.; Baranyai, P. Anion-, Solvent-, Temperature-, and Mechano-Responsive Photoluminescence in Gold(I) Diphosphine-Based Dimers. Chem. A Eur. J. 2015, 21, 11495-11508. [CrossRef]

43. Aljuhani, M.A.; Bootharaju, M.S.; Sinatra, L.; Basset, J.M.; Mohammed, O.F.; Bakr, O.M. Synthesis and Optical Properties of a Dithiolate/Phosphine-Protected $\mathrm{Au}_{28}$ Nanocluster. J. Phys. Chem. C 2017, 121, 10681-10685. [CrossRef]

44. Negishi, Y.; Takasugi, Y.; Sato, S.; Yao, H.; Kimura, K.; Tsukuda, T. Kinetic stabilization of growing gold clusters by passivation with thiolates. J. Phys. Chem. B 2006, 110, 12218-12221. [CrossRef]

45. Le Guével, X.; Spies, C.; Daum, N.; Jung, G.; Schneider, M. Highly fluorescent silver nanoclusters stabilized by glutathione: A promising fluorescent label for bioimaging. Nano Res. 2012, 5, 379-387. [CrossRef]

46. Bayse, C.A.; Ming, J.L.; Miller, K.M.; McCollough, S.M.; Pike, R.D. Photoluminescence of silver(I) and gold(I) cyanide 1D coordination polymers. Inorg. Chim. Acta 2011, 375, 47-52. [CrossRef]

47. Luo, Z.; Yuan, X.; Yu, Y.; Zhang, Q.; Leong, D.T.; Lee, J.Y.; Xie, J. From Aggregation-Induced Emission of $\mathrm{Au}(\mathrm{I})$-Thiolate Complexes to Ultrabright $\mathrm{Au}(0) @ \mathrm{Au}(\mathrm{I})-$ Thiolate Core-Shell Nanoclusters. J. Am. Chem. Soc. 2012, 134, 16662-16670. [CrossRef]

48. Ahmad, A.; Senapati, S.; Khan, M.I.; Kumar, R.; Ramani, R.; Srinivas, V.; Sastry, M. Intracellular synthesis of gold nanoparticles by a novel alkalotolerant actinomycete, Rhodococcus species. Nanotechnology 2003, 14, 824-828. [CrossRef]

49. Feng, Y.; Lin, X.; Wang, Y.; Wang, Y.; Hua, J. Diversity of Aurum bioreduction by Rhodobacter capsulatus. Mater. Lett. 2008, 62, 4299-4302. [CrossRef]

50. Nune, S.K.; Chanda, N.; Shukla, R.; Katti, K.; Kulkarni, R.R.; Thilakavathy, S.; Mekapothula, S.; Kannan, R.; Katti, K.V. Green nanotechnology from tea: Phytochemicals in tea as building blocks for production of biocompatible gold nanoparticles. J. Mater. Chem. 2009, 19, 2912-2920. [CrossRef] 
51. Kasthuri, J.; Veerapandian, S.; Rajendiran, N. Biological synthesis of silver and gold nanoparticles using apiin as reducing agent. Colloids Surf. B Biointerfaces 2009, 68, 55-60. [CrossRef]

52. Vemula, P.K.; Aslam, U.; Mallia, V.A.; John, G. In situ synthesis of gold nanoparticles using molecular gels and liquid crystals from vitamin-C amphiphiles. Chem. Mater. 2007, 19, 138-140. [CrossRef]

53. Lee, J.; Ryu, J.; Choi, W. Preparation of Gold and Platinum Nanoparticles Using Visible Light Activated Fe III -complex. Chem. Lett. 2007, 36, 176-177. [CrossRef]

54. Nasr, G.; Guerlin, A.; Dumur, F.; Baudron, S.A.; Dumas, E.; Miomandre, F.; Clavier, G.; Sliwa, M.; Mayer, C.R. Dithiolate-appended iridium(III) complex with dual functions of reducing and capping agent for the design of small-sized gold nanoparticles. J. Am. Chem. Soc. 2011, 133, 6501-6504. [CrossRef]

55. Kasthuri, J.; Rajendiran, N. Functionalization of silver and gold nanoparticles using amino acid conjugated bile salts with tunable longitudinal plasmon resonance. Colloids Surf. B Biointerfaces 2009, 73, 387-393. [CrossRef]

56. Huang, T.; Meng, F.; Qi, L. Controlled synthesis of dendritic gold nanostructures assisted by supramolecular complexes of surfactant with cyclodextrin. Langmuir 2010, 26, 7582-7589. [CrossRef]

57. Hussain, I.; Brust, M.; Papworth, A.J.; Cooper, A.I. Preparation of Acrylate-Stabilized Gold and Silver Hydrosols and Gold-Polymer Composite Films. Langmuir 2003, 19, 4831-4835. [CrossRef]

58. Sardar, R.; Park, J.W.; Shumaker-Parry, J.S. Polymer-induced synthesis of stable gold and silver nanoparticles and subsequent ligand exchange in water. Langmuir 2007, 23, 11883-11889. [CrossRef]

59. Meldrum, F.C.; Heywood, B.R.; Mann, S. Influence of Membrane Composition on the Intravesicular Precipitation of Nanophase Gold Particles. J. Colloid Interface Sci. 1993, 161, 66-71. [CrossRef]

60. Wangoo, N.; Kaur, S.; Bajaj, M.; Jain, D.V.S.; Sharma, R.K. One pot, rapid and efficient synthesis of water dispersible gold nanoparticles using alpha-amino acids. Nanotechnology 2014, 25, 435608. [CrossRef]

61. Mandal, S.; Selvakannan, P.R.; Phadtare, S.; Pasricha, R.; Sastry, M. Synthesis of a stable gold hydrosol by the reduction of chloroaurate ions by the amino acid, aspartic acid. Proc. Indian Acad. Sci. Chem. Sci. 2002, 114, 513-520. [CrossRef]

62. Selvakannan, P.R.; Mandal, S.; Phadtare, S.; Pasricha, R.; Sastry, M. Capping of gold nanoparticles by the amino acid lysine renders them water-dispersible. Langmuir 2003, 19, 3545-3549. [CrossRef]

63. Selvakannan, P.R.; Mandal, S.; Phadtare, S.; Gole, A.; Pasricha, R.; Adyanthaya, S.D.; Sastry, M. Water-dispersible tryptophan-protected gold nanoparticles prepared by the spontaneous reduction of aqueous chloroaurate ions by the amino acid. J. Colloid Interface Sci. 2004, 269, 97-102. [CrossRef]

64. Bhargava, S.K.; Booth, J.M.; Agrawal, S.; Coloe, P.; Kar, G. Gold nanoparticle formation during bromoaurate reduction by amino acids. Langmuir 2005, 21, 5949-5956. [CrossRef]

65. Newman, J.D.S.S.D.S.; Blanchard, G.J.J. Formation of gold nanoparticles using amine reducing agents. Langmuir 2006, 22, 5882-5887. [CrossRef]

66. Wangoo, N.; Bhasin, K.K.; Mehta, S.K.; Suri, C.R. Synthesis and capping of water-dispersed gold nanoparticles by an amino acid: Bioconjugation and binding studies. J. Colloid Interface Sci. 2008, 323, 247-254. [CrossRef]

67. Liu, Z.; Zu, Y.; Fu, Y.; Meng, R.; Guo, S.; Xing, Z.; Tan, S. Hydrothermal synthesis of histidine-functionalized single-crystalline gold nanoparticles and their $\mathrm{pH}$-dependent UV absorption characteristic. Colloids Surf. B Biointerfaces 2010, 76, 311-316. [CrossRef]

68. Cai, H.; Yao, P. Gold nanoparticles with different amino acid surfaces: Serum albumin adsorption, intracellular uptake and cytotoxicity. Colloids Surf. B Biointerfaces 2014, 123, 900-906. [CrossRef]

69. Courrol, L.C.; de Matos, R.A. Synthesis of Gold Nanoparticles Using Amino Acids by Light Irradiation. In Catalytic Application of Nano-Gold Catalysts; InTech: Bergharen, The Netherlands, 2016; Volume i, p. 13.

70. Maruyama, T.; Fujimoto, Y.; Maekawa, T. Synthesis of gold nanoparticles using various amino acids. J. Colloid Interface Sci. 2014, 447, 254-257. [CrossRef]

71. Csapó, E.; Ungor, D.; Kele, Z.; Baranyai, P.; Deák, A.; Juhász, Á.; Janovák, L.; Dékány, I. Influence of pH and aurate/amino acid ratios on the tuneable optical features of gold nanoparticles and nanoclusters. Colloids Surf. A Physicochem. Eng. Asp. 2017, 532, 601-608. [CrossRef]

72. Zhang, L.; Wang, E. Metal nanoclusters: New fluorescent probes for sensors and bioimaging. Nano Today 2014, 9, 132-157. [CrossRef]

73. Khandelwal, P.; Poddar, P. Fluorescent metal quantum clusters: An updated overview of the synthesis, properties, and biological applications. J. Mater. Chem. B 2017, 5, 9055-9084. [CrossRef] 
74. Shang, L.; Dong, S.; Nienhaus, G.U. Ultra-small fluorescent metal nanoclusters: Synthesis and biological applications. Nano Today 2011, 6, 401-418. [CrossRef]

75. Chevrier, D.M.; Chatt, A.; Zhang, P. Properties and applications of protein-stabilized fluorescent gold nanoclusters: Short review. J. Nanophotonics 2012, 6, 064504. [CrossRef]

76. Ungor, D.; Horváth, K.; Dékány, I.; Csapó, E. Red-emitting gold nanoclusters for rapid fluorescence sensing of tryptophan metabolites. Sens. Actuators B Chem. 2019, 288, 728-733. [CrossRef]

77. Tsunoyama, H.; Tsukuda, T. Magic numbers of gold clusters stabilized by PVP. J. Am. Chem. Soc. 2009, 131, 18216-18217. [CrossRef]

78. Li, Z.; Liu, R.; Xing, G.; Wang, T.; Liu, S. A novel fluorometric and colorimetric sensor for iodide determination using DNA-templated gold/silver nanoclusters. Biosens. Bioelectron. 2017, 96, 44-48. [CrossRef]

79. Zheng, J.; Petty, J.T.; Dickson, R.M. High Quantum Yield Blue Emission from Water-Soluble Au 8 Nanodots. J. Am. Chem. Soc. 2003, 125, 7780-7781. [CrossRef]

80. Zheng, J.; Nicovich, P.R.; Dickson, R.M. Highly Fluorescent Noble-Metal Quantum Dots. Annu. Rev. Phys. Chem. 2007, 58, 409-431. [CrossRef]

81. Zheng, J.; Zhou, C.; Yu, M.; Liu, J. Different sized luminescent gold nanoparticles. Nanoscale 2012, 4, 4073. [CrossRef]

82. Yang, X.; Shi, M.; Zhou, R.; Chen, X.; Chen, H. Blending of $\mathrm{HAuCl}_{4}$ and histidine in aqueous solution: A simple approach to the $\mathrm{Au}_{10}$ cluster. Nanoscale 2011, 3, 2596-2601. [CrossRef]

83. Zhang, X.; Wu, F.G.; Liu, P.; Gu, N.; Chen, Z. Enhanced fluorescence of gold nanoclusters composed of $\mathrm{HAuCl}_{4}$ and histidine by glutathione: Glutathione detection and selective cancer cell imaging. Small 2014, 10, 5170-5177. [CrossRef]

84. Liu, X.; Yu, X.; Luo, X. Ultrasensitive iodide detection based on the resonance light scattering of histidine-stabilized gold nanoclusters. Microchim. Acta 2014, 181, 1379-1384. [CrossRef]

85. Schmidt, L.A.; Kirk, L.; Appleman, W.K. The Appaern Dissociation costants of Arginine and of Lysine and the Apparent Heats of Ionization of Certain Amino Acids. J. Biol. Chem. 1930, 88, 285-293.

86. Zhang, Y.; Hu, Q.; Paau, M.C.; Xie, S.; Gao, P.; Chan, W.; Choi, M.M.F. Probing histidine-stabilized gold nanoclusters product by high-performance liquid chromatography and mass spectrometry. J. Phys. Chem. C 2013, 117, 18697-18708. [CrossRef]

87. Guo, Y.; Long, T.; Lin, M.; Liu, Z.; Huang, C.; Zhao, X. Histidine-mediated synthesis of chiral fluorescence gold nanoclusters: Insight into the origin of nanoscale chirality. RSC Adv. 2015, 5, 61449-61454. [CrossRef]

88. Yang, X.; Luo, Y.; Zhuo, Y.; Feng, Y.; Zhu, S. Novel synthesis of gold nanoclusters templated with $L$-tyrosine for selective analyzing tyrosinase. Anal. Chim. Acta 2014, 840, 87-92. [CrossRef]

89. Mu, X.; Qi, L.; Qiao, J.; Ma, H. One-pot synthesis of tyrosine-stabilized fluorescent gold nanoclusters and their application as turn-on sensors for $\mathrm{Al}^{3+}$ ions and turn-off sensors for $\mathrm{Fe}^{3+}$ ions. Anal. Methods 2014, 6, 6445-6451. [CrossRef]

90. Mu, X.; Qi, L.; Dong, P.; Qiao, J.; Hou, J.; Nie, Z.; Ma, H. Facile one-pot synthesis of L-proline-stabilized fluorescent gold nanoclusters and its application as sensing probes for serum iron. Biosens. Bioelectron. 2013, 49, 249-255. [CrossRef]

91. Zheng, S.; Yin, H.; Li, Y.; Bi, F.; Gan, F. One-step synthesis of L-tryptophan-stabilized dual-emission fluorescent gold nanoclusters and its application for $\mathrm{Fe}^{3+}$ sensing. Sens. Actuators B Chem. 2017, 242, 469-475. [CrossRef]

92. Deng, H.H.; Zhang, L.N.; He, S.B.; Liu, A.L.; Li, G.W.; Lin, X.H.; Xia, X.H.; Chen, W. Methionine-directed fabrication of gold nanoclusters with yellow fluorescent emission for $\mathrm{Cu}^{2+}$ sensing. Biosens. Bioelectron. 2015, 65, 397-403. [CrossRef]

93. Csapó, E.; Ungor, D.; Juhász, Á.; Tóth, G.K.; Dékány, I. Gold nanohybrid systems with tunable fluorescent feature: Interaction of cysteine and cysteine-containing peptides with gold in two- and three-dimensional systems. Colloids Surf. A Physicochem. Eng. Asp. 2016, 511, 264-271. [CrossRef]

94. Söptei, B.; Mihály, J.; Szigyártó, I.C.; Wacha, A.; Németh, C.; Bertóti, I.; May, Z.; Baranyai, P.; Sajó, I.E.; Bóta, A. The supramolecular chemistry of gold and $L$-cysteine: Formation of photoluminescent, orange-emitting assemblies with multilayer structure. Colloids Surf. A Physicochem. Eng. Asp. 2015, 470, 8-14. [CrossRef]

95. Jin, R. Quantum sized, thiolate-protected gold nanoclusters. Nanoscale 2010, 2, 343-362. [CrossRef]

96. Nasaruddin, R.R.; Chen, T.; Yan, N.; Xie, J. Roles of thiolate ligands in the synthesis, properties and catalytic application of gold nanoclusters. Coord. Chem. Rev. 2018, 368, 60-79. [CrossRef] 
97. Xavier, P.L.; Chaudhari, K.; Baksi, A.; Pradeep, T. Protein-protected luminescent noble metal quantum clusters: An emerging trend in atomic cluster nanoscience. Nano Rev. 2012, 3, 14767. [CrossRef]

98. Yee, C.K.; Jordan, R.; Ulman, A.; White, H.; King, A.; Rafailovich, M.; Sokolov, J. Novel One-Phase Synthesis of Thiol-Functionalized Gold, Palladium, and Iridium Nanoparticles Using Superhydride. Langmuir 1999, 15, 3486-3491. [CrossRef]

99. Frenkel, A.I.; Nemzer, S.; Pister, I.; Soussan, L.; Harris, T.; Sun, Y.; Rafailovich, M.H. Size-controlled synthesis and characterization of thiol-stabilized gold nanoparticles. J. Chem. Phys. 2005, 123, 184701. [CrossRef]

100. Perala, S.R.K.; Kumar, S. On the Mechanism of Metal Nanoparticle Synthesis in the Brust-Schiffrin Method. Langmuir 2013, 29, 9863-9873. [CrossRef]

101. Yu, C.; Zhu, L.; Zhang, R.; Wang, X.; Guo, C.; Sun, P.; Xue, G. Investigation on the Mechanism of the Synthesis of Gold(I) Thiolate Complexes by NMR. J. Phys. Chem. C 2014, 118, 10434-10440. [CrossRef]

102. Briñas, R.P.; Hu, M.; Qian, L.; Lymar, E.S.; Hainfeld, J.F. Gold Nanoparticle Size Controlled by Polymeric $\mathrm{Au}(\mathrm{I})$ Thiolate Precursor Size. J. Am. Chem. Soc. 2008, 130, 975-982. [CrossRef]

103. Schaaff, T.G.; Whetten, R.L. Giant Gold-Glutathione Cluster Compounds: Intense Optical Activity in Metal-Based Transitions. J. Phys. Chem. B 2000, 104, 2630-2641. [CrossRef]

104. Negishi, Y.; Takasugi, Y.; Sato, S.; Yao, H.; Kimura, K.; Tsukuda, T.; Characterization, S.; Tsukuda, T. Magic-Numbered $\mathrm{Au}_{\mathrm{n}}$ Clusters Protected by Glutathione Monolayers ( $\left.\mathrm{n}=18,21,25,28,32,39\right)$ : Isolation and Spectroscopic Characterization. J. Am. Chem. Soc. 2004, 126, 6518-6519. [CrossRef]

105. Negishi, Y.; Nobusada, K.; Tsukuda, T. Glutathione-Protected Gold Clusters Revisited: Bridging the Gap between Gold(I)-Thiolate Complexes and Thiolate-Protected Gold Nanocrystals. J. Am. Chem. Soc. 2005, 127, 5261-5270. [CrossRef]

106. Bachman, R.E.; Bodolosky-Bettis, S.A.; Glennon, S.C.; Sirchio, S.A. Formation of a Novel Luminescent Form of Gold(I) Phenylthiolate via Self-Assembly and Decomposition of Isonitrilegold(I) Phenylthiolate Complexes. J. Am. Chem. Soc. 2000, 122, 7146-7147. [CrossRef]

107. Odriozola, I.; Loinaz, I.; Pomposo, J.A.; Grande, H.J. Gold-glutathione supramolecular hydrogels. J. Mater. Chem. 2007, 17, 4843. [CrossRef]

108. Nie, H.; Li, M.; Hao, Y.; Wang, X.; Zhang, S.X.A. Time-resolved monitoring of dynamic self-assembly of $\mathrm{Au}(\mathrm{I})$-thiolate coordination polymers. Chem. Sci. 2013, 4, 1852. [CrossRef]

109. Royappa, A.T.; Tran, C.M.; Papoular, R.J.; Khan, M.; Marbella, L.E.; Millstone, J.E.; Gembicky, M.; Chen, B.; Shepard, W.; Elkaim, E. Copper(I) and gold(I) thiolate precursors to bimetallic nanoparticles. Polyhedron 2018, 155, 359-365. [CrossRef]

110. Cappellari, P.S.; Buceta, D.; Morales, G.M.; Barbero, C.A.; Sergio Moreno, M.; Giovanetti, L.J.; Ramallo-López, J.M.; Requejo, F.G.; Craievich, A.F.; Planes, G.A. Synthesis of ultra-small cysteine-capped gold nanoparticles by $\mathrm{pH}$ switching of the $\mathrm{Au}(\mathrm{I})$-cysteine polymer. J. Colloid Interface Sci. 2015, 441, 17-24. [CrossRef]

111. Habeeb Muhammed, M.A.; Verma, P.K.; Pal, S.K.; Retnakumari, A.; Koyakutty, M.; Nair, S.; Pradeep, T. Luminescent Quantum Clusters of Gold in Bulk by Albumin-Induced Core Etching of Nanoparticles: Metal Ion Sensing, Metal-Enhanced Luminescence, and Biolabeling. Chem. A Eur. J. 2010, 16, 10103-10112. [CrossRef]

112. Hemmateenejad, B.; Shakerizadeh-shirazi, F.; Samari, F. BSA-modified gold nanoclusters for sensing of folic acid. Sens. Actuators B Chem. 2014, 199, 42-46. [CrossRef]

113. Zhao, S.; Li, Z.; Li, Y.; Yu, J.; Liu, G.; Liu, R.; Yue, Z. BSA-AuNCs based enhanced photoelectrochemical biosensors and its potential use in multichannel detections. J. Photochem. Photobiol. A Chem. 2017, 342, $15-24$. [CrossRef]

114. Gui, R.; Jin, H. Aqueous synthesis of human serum albumin-stabilized fluorescent Au/Ag core/shell nanocrystals for highly sensitive and selective sensing of copper(II). Analyst 2013, 138, 7197. [CrossRef]

115. Yu, Y.; New, S.Y.; Xie, J.; Su, X.; Tan, Y.N. Protein-based fluorescent metal nanoclusters for small molecular drug screening. Chem. Commun. 2014, 50, 13805-13808. [CrossRef]

116. Wei, H.; Wang, Z.; Yang, L.; Tian, S.; Hou, C.; Lu, Y. Lysozyme-stabilized gold fluorescent cluster: Synthesis and application as $\mathrm{Hg}^{2+}$ sensor. Analyst 2010, 135, 1406. [CrossRef]

117. Chan, P.H.; Wong, S.Y.; Lin, S.H.; Chen, Y.C. Lysozyme-encapsulated gold nanocluster-based affinity mass spectrometry for pathogenic bacteria. Rapid Commun. Mass Spectrom. 2013, 27, 2143-2148. [CrossRef] 
118. Lu, D.; Liu, L.; Li, F.; Shuang, S.; Li, Y.; Choi, M.M.F.; Dong, C. Lysozyme-stabilized gold nanoclusters as a novel fluorescence probe for cyanide recognition. Spectrochim. Acta Part A Mol. Biomol. Spectrosc. 2014, 121, 77-80. [CrossRef]

119. Hornok, V.; Csapó, E.; Varga, N.; Ungor, D.; Sebők, D.; Janovák, L.; Laczkó, G.; Dékány, I. Controlled syntheses and structural characterization of plasmonic and red-emitting gold/lysozyme nanohybrid dispersions. Colloid Polym. Sci. 2016, 294, 49-58. [CrossRef]

120. Russell, B.A.A.; Jachimska, B.; Komorek, P.; Mulheran, P.A.A.; Chen, Y. Lysozyme encapsulated gold nanoclusters: Effects of cluster synthesis on natural protein characteristics. Phys. Chem. Chem. Phys. 2017, 19, 7228-7235. [CrossRef]

121. Kawasaki, H.; Yoshimura, K.; Hamahuchi, K.; Arakawa, R. Trypsin-Stabilized Fluorescent Gold Nanocluster for Sensitive and Selective $\mathrm{Hg}^{2+}$ Detection. Anal. Sci. 2011, 27, 591. [CrossRef]

122. Kawasaki, H.; Hamaguchi, K.; Osaka, I.; Arakawa, R. pH-Dependent Synthesis of Pepsin-Mediated Gold Nanoclusters with Blue Green and Red Fluorescent Emission. Adv. Funct. Mater. 2011, 21, 3508-3515. [CrossRef]

123. Zhu, M.; Aikens, C.M.; Hollander, F.J.; Schatz, G.C.; Jin, R. Correlating the Crystal Structure of A Thiol-Protected $\mathrm{Au}_{25}$ Cluster and Optical Properties. J. Am. Chem. Soc. 2008, 130, 5883-5885. [CrossRef]

124. Zhou, R.; Shi, M.; Chen, X.; Wang, M.; Chen, H. Atomically Monodispersed and Fluorescent Sub-Nanometer Gold Clusters Created by Biomolecule-Assisted Etching of Nanometer-Sized Gold Particles and Rods. Chem. A Eur. J. 2009, 15, 4944-4951. [CrossRef]

125. Xie, J.; Zheng, Y.; Ying, J.Y. Protein-Directed Synthesis of Highly Fluorescent Gold Nanoclusters. J. Am. Chem. Soc. 2009, 131, 888-889. [CrossRef]

126. Chaudhari, K.; Xavier, P.L.; Pradeep, T. Understanding the Evolution of Luminescent Gold Quantum Clusters in Protein Templates. ACS Nano 2011, 5, 8816-8827. [CrossRef]

(C) 2019 by the authors. Licensee MDPI, Basel, Switzerland. This article is an open access article distributed under the terms and conditions of the Creative Commons Attribution (CC BY) license (http://creativecommons.org/licenses/by/4.0/). 